\title{
EXPLORING THE EFFECTS OF FLEXIBLE WORKING PRACTICES AND FAMILY FRIENDLY POLICIES ON THE EMPLOYMENT AND WELFARE OF INSECURE WORKERS
}

\author{
MOHAMED BRANINE \\ DUNDEE BUSINESS SCHOOL \\ UNIVERSITY OF ABERTAY, SCOTLAND, WIELKA BRYTANIA
}

\begin{abstract}
Summary: This paper raises a number of controversial issues in an attempt to evaluate the effects of flexible working practices and family friendly policies on employment and welfare of mainly people with disabilities, senior citizens and the women and men with caring responsibilities. Over the recent years many governments have championed the idea of flexible working for obvious political and economic motives while most employers who have accepted or even initiated such practices and policies have acted on purely economic and business grounds. This study attempts to explain the concepts of flexible working and family friendly policy and then to explore the reasons for and procedures of implementing such policies. It is concluded that family friendly policies can be useful means of meeting the needs of both employers and employees, depending on the way they are implemented and the people who benefit from them.
\end{abstract}

Keywords: flexible working practices, family friendly policies, flexibility in work place

\section{Introduction}

Recent trends and developments in the global labour market have given rise to different views and concerns about the real beneficiaries of implementing flexible working practices and introducing family friendly policies. However, since earlier claims of the flexible firm with its needs and its objectives at economic, political, social and organizational level (Atkinson, 1984; 1987) and the criticisms it generated after that (see Pollert, 1988 a.b), the debate has been at loggerheads and has taken different dimensions. Many studies have been carried out in both public and private sector organizations (e.g. Corby, 1991; Snell, 1995; Baker, 1996; Northrop, 1998; Branine, 1998; 2003; 2004; Fagan, 2003; Greenhaus et al., 2006; Holt and Lewis, 2011; Bloom et al., 2011; Hegewisch and Gornick, 2011; Beham et al., 2013) but there is no conclusive evidence as to whether or not employment and welfare problems of those affected have been elevated. It is frequently argued that if implemented successfully family friendly policies will benefit employers and employees. For example, the British government stipulated that the implementation of family friendly policies was important to many employers and employees, and made available 'a pot of money specifically to pay for advice to selected employers on implementing a better work/life balance' (Arnold and Bevan, Financial Times, 5 October 2000). The production of the Green Paper on Supporting Families and 
Meeting the Childcare Challenge (Dof EE, September, 1999) and the introduction of Working Family Tax Credit in 2000 and the Children Tax Credit in April 2001 have been all initiatives by the government to help employees balance their work with family commitments, and employers meet their demands for labour.

On the one hand, it is often argued that the main benefits to employers are retaining employees over variable periods of business demands; promoting employee commitment and job satisfaction; reducing costs of recruiting, selecting and training of new employees; reaching a wider pool of potential employees when advertising for new jobs; linking outcomes to individual performance rather than to the length of time spent at work; and having lower rate of absenteeism and maximum utilization of tools, equipment and machinery. Whereas the main benefits to employees are providing an opportunity to combine paid work with other commitments; providing flexibility in determining how, where and when to work; and providing stability in employment career, as one does not have to change jobs or be unemployed.

It is argued that flexible working practices and family friendly policies are effective ways of providing an opportunity for an increasing number of employees to get paid employment. Employers are responding to market demands by recognising and accommodating the needs of an increasingly diverse labour market. Many employers have introduced employment policies that are particularly attractive to the so-called disadvantaged groups (disabled, old, women and ethnic minorities) to enable them to remain in the labour market as active and productive members of society. According to IRS Employment Trends (no. 688, 1999: 5) flexible working became a means by which many organizations are able to achieve their business objectives while at the same time attempting to respond to a growing demand by employees for flexible working in order to balance between work and family commitments. It is also very often argued that there are socio-economic factors that make working flexibly more attractive to some employees than full-time work. Many studies have shown that organizations improved staff retention by offering their employees 'more flexible working options and by implementing other family friendly policies' (IDS Study, 692, July, 2000: 8). For example, by the early 1990s there were more than 74 percent of those employed part-time in the UK who did not want to work full-time and only 13 percent did so because they could not find a full-time employment (Naylor, 1994; Brooks, 2000).

On the other hand, however, many reports and studies appear to indicate that flexible working practices and family friendly policies are merely a means of exploitation of labour by employers especially in times of financial crisis and depressed economic conditions (Pollert, 1988; Hakim, 1990). Flexible working practices are very often associated with the exploitation of employees when considering the type of people who work flexibly and the type of jobs they do. It is argued that those who work flexibly are often employed in lower paid and lower status jobs in which there is little access to training and fewer opportunities for 
promotion (Overell, 1995; Gherardi and Murgia, 2012; Bolton and Laaser, 2013; Stuart, et al. 2013). For example, many women who return to work part-time, after maternity leave, experience downward mobility and are segregated from full-time employees. Part-time work is a trap leading to the marginalization of women in the labour market because most of the part-timers do not have the kind of training and development opportunities that might help them to get promoted (Beechey and Perkins, 1997; Branine, 2003). According to Philips (1997: 9) 'part-time work can hardly be said to be attractive as it is poorly paid, is insecure, lacks prospects for advancement, and often does not benefit from employment protection legislation or national insurance. This is mainly because flexible hours are usually arranged for the convenience of the employer and 'do not necessarily help employees balance their day-for family/leisure needs' and that 'flexibility is solely to suit employers' needs' (IRS Employment Trends, August, 1995: 1). The experience of combining family and employment responsibilities is found to have caused stress and work overload leading to 'poorer health, stress-related illness, reduced quality of life and even family conflict and break up' (IRS Employment Trends, April, 1995: 2). Moreover, according to Winstanley and Woodall (2000: 143) 'part-time work is used by employers to avoid paying overtime premia to full-time staff, part-time workers are often expected to work "unsocial" hours and hours of work are sometimes changed at short notice, resulting in unpredictable earnings'. The issue of job security is often raised in this context because it is argued that flexible working and family friendly policies undermine job security, creating a risk society (O'Reilly and Rose, 1998; Brown et al., 1997). Some employees may not consider the options of working flexibly because of the fear of becoming vulnerable to exploitation.

To shed some light on the above arguments this paper will attempt to define the concept of family-friendly policies, consider the factors that have led to employers introducing them, and examine whether they are a means of exploitation or merely a good employment practice that benefits both the employee and the employer.

\section{Family-Friendly policies: a catch phrase}

In a comprehensive definition by Lewis and Lewis (1996:5) 'organizations are often described as "family-friendly" on the basis of the number of formal policies initiated to meet the needs of employees with family commitments' and they argued that policies defined as family friendly must meet four objectives:

1) Enabling employees to fulfil 'the demands of both family and work';

2) promoting equal opportunities;

3) providing 'acceptable working conditions and practices which are non-discriminatory and employee-friendly'; and

4) balancing 'the needs of the employer with the needs of the employee'. In short, the term 'family-friendly policies' is used to describe employment policies that may help employees to combine between work and family 
commitments and is a catch phrase that includes a wide range of provisions that can be classified into three initiatives:

I. Leave for family reasons such as maternity and paternity leave, school holidays leave, wedding and funeral attendance, career breaks and sabbaticals, and breaks as a result of a problem or illness in the family.

II. Flexible working practices such as job sharing, part-time work, annual hours, home-based working, flexi-time, flexi-place and so forth (as explained in more details below).

III.Dependent care policies that are introduced to provide direct services like childcare, elderly care and disabled care centres on site or nearer to the workplace. Childcare facilities such as crèche availability, vouchers allowances and holiday provisions. Elderly care facilities such as home care visits, clubs services and medical attendance. Disabled care facilities such as the provision of transport, accessibility, and medical help and so on. Caring for an elderly parent, partner or relative is essential for an increasing number of employees. Although 'all the reasons given to support childcare provisions apply equally well to those provisions for caring for older relatives' (Stredwick and Ellis, 1998: 249) 'elder care has received limited attention from employers' (Lewis and Lewis (1996: 52). Disabled care facilities should be understood as those that support employees with disabilities and those who have to care for a disabled relative or friend. Such provisions may include the transportation of disabled employees to work. This may also be used for hospital and doctors appointments and visits. Within organizations, provisions such as wide doors, ramps and lifts, appropriate furniture, and convenient rest rooms have to be made to allow disabled employees, clients and customers easy access.

Flexible working practices are used by an increasing number of employers as a means of achieving a family friendly policy. In fact family-friendly policies are closely related to the increase of flexibility in working arrangements. Flexible working practices have increased in popularity in order to meet the demands for family-friendly working arrangements. According to Pettinger (1998; 1), flexible working is 'used to describe the creation of work patterns and arrangements based on the need to maximize and optimize organizational output, customer satisfaction and staff expertise and effectiveness'. Organizations introduce flexible working practices in order to 'make full use of talented persons who (for a variety of reasons) are unable to work regular or traditional patterns or hours, and to harmonize their capabilities with the demands of customers and the requirements of organizations' (Pettinger, 1998: 2). The most common forms of flexible working are part-time work, flexitime, job sharing and home-based working.

In the UK the difference between full-time and part-time work is not legally defined. For statistical purposes, the term 'part-time' is generally applied to those 
wo work no more than 30 hours per week. Although it has always existed, part-time work has increased significantly over the last 50 years, moving from approximately 2.7 percent of those employed in 1951 to 15.5 percent in 1991 and to 26 percent in 1991 (IDS, 1993). Part-time work is currently the most popular form of flexible working which can be found virtually in every sector of the economy. Most of the part-time jobs are concentrated in four areas: a) sales and services such as supermarket check out staff, shop assistants, cleaners, shelving staff and porters; 2) education and health, especially nurses and school teachers; 3) personal clients' services such as hairdressers, fast food restaurants, and entertainment services staff; and 4) clerical and secretarial jobs.

There has been also a significant growth in other forms of flexible working practices such as job sharing which has been used as a way of extending part-time work to managerial and professional positions. Job sharing is an arrangement where two employees share the work of one full-time position. Salary, leave and benefits are divided between them according to the amount of time each person works (Curson, 1986; Branine, 1998). Job sharers are responsible for the entire job and in return retain the prospects and status of full-time employees. This makes professional and managerial posts open to job sharing and, as Meager, Buchan and Rees (1990) put it, jobs with high levels of responsibility and complex job content become available to those who want to balance between their work and other interests. According to an IDS report, job sharing in the UK doubled between 1990 and 2000 to stand at about 200,000 job sharers (IDS, Study 695, September 2000: 1).

Flexible working hours are also used very widely in the UK as 'a scheme of working which allows employees to choose the time they begin and finish work around a set core time during each working day. This provides an opportunity for employees to exercise discretion over the arrangement of their working hours' (Wooding, 1995: 30). Such flexitime systems work on the premise that an element of time is classed as core, during which staff should be present at the workplace. Outside this time, employees can use their discretion over when they begin and finish work. It is also permitted to carry over any excess or deficit in hours beyond an accounting period (either a year or a month depending on agreement). The scheme allows employees to compress some of their working weeks into fewer working days without reducing the total hours. The flexibility of working hours can be offered by employers as part of their family friendly policies where employees, for example, work longer hours on days when their children are at school to enable them to be at home during school holidays.

Another form of flexible working that has been made possible by advances in information technologies is the home-based working and tele-working. It provides the 'capacity to work from home for short, long or permanent periods of time and to receive remuneration from an employer in line with those who attend a regular workplace (Wooding, 1995; 62). The use of computers and the advancement in information technology have made the use of home-based working more and more 
possible and widely popular. There are many job opportunities for employees to work from home such as consultants, designers and programmers not just secretaries and sales representatives. Wooding (1995: 66) argued that 'the concept of the portable office has become commonplace and affordable when set against the benefits of retaining staff or reducing office leasing costs. One of the major advantages of home-based working is that overheads are kept at an absolute minimum: a strategy, which can only improve an organization's competitive advantage. When home-based workers are classified as self-employed the employers' contribution towards income tax and national insurance will also be saved.

\section{Flexible working and family friendly policies: the debate}

The 'flexibility debate' has been conducted to a great extent at the macro-level while empirical evidence from organizations at the workplace is still limited and controversial, as eluded to in the introduction to this paper. There is no doubt that working arrangements other than full-time employment have increased in various forms over the last three decades or so and, as a result, it seems that both employers and employees concerned have benefited from such arrangements that have made it possible for many employers to attract and retain employees who are given the opportunity to combine work with other commitments. There are many explanations related to economic, demographic, social, technological and cultural factors for the upsurge in the use of flexible working practices and the introduction of family friendly policies.

The demographic factors include the availability of many older and healthier people and increasing number of people with disabilities who look for jobs because they can make a significant contribution to the economy as well as the women and men with family and caring commitments that prefer to work flexibly. In many European countries, more than a third of the population is over 40 years old and it is estimated that the number of people over the age of 80 could reach 25 million by 2020 (see Eurostat, 1999). In the UK there is almost exactly the same number of children under the age 16 as there are over the age of 60 , about 12 million people in each age group. Employers who rely on young people will be forced to review their employment policies as the workforce becomes predominantly older. Moreover, the number of people with various disabilities but seeking employment is also in the increase. By the end of the 1990s there were 3.9 million disabled people of working age in the UK (Bach and Sisson, 2000: 142) and this is too large a proportion of the workforce that should not be underestimated.

The economic factors include the need for efficiency and cost-reductions because of increasing business uncertainty and global competition. Flexible working is seen important for retaining employees and thus reducing recruitment and replacement costs. According to Wooding (1995: 3) 'the move towards greater flexibility within organizations and the operation of work has been fuelled by the 
needs of employers searching to reduce the costs attached to replacing experienced and trained staff. At the same time driven by these staff in an attempt to reconcile domestic and paid work activity, who has requested more flexible opportunities for working.

The social factors that created the necessity for flexible working include the nuclear family, the one parent family, the breaking up family, the working family, the educated family and other values related to individuals and groups of people in society. Significant social changes such as the growth of dual earner and lone parent households as marriages decline and divorces rise, women have attained greater financial and social independence and motherhood is no longer dominating a women's life. The increasing participation of women in the labour force is due changing family structures and values, rising living standards and the increasing general awareness by women of their role in society. For example, from 1975 to 1995 the number of employed women in the UK increased by 34 percent to 12.2 million (Torrington and Hall, 1998). However, many employers may see the introduction of family friendly policies as part of their equal opportunities strategy in an attempt to supposedly offer equality of employment to all potential and existing employees. Lewis and Lewis (1996) argued that family friendly policies had been introduced in response to women's growing participation in the labour force because such policies were used primarily to enable mothers to combine employment with childcare. Employers' assistance with childcare improves the retention of staff and enhances the organization's image when seeking to employ female employees. Also, Barnes (1992) argued that using flexible working practices as an equal opportunities initiative may help the disabled to get decent and respectable jobs because at present many disabled people are either out of work or are employed in low skilled jobs with poor working conditions and little job security or opportunity for advancement.

It can be argued that some employers who introduce family friendly policies as a means of implementing their equal opportunities policies do so simply in order to adhere to existing laws against discrimination by recruiting from groups that have been traditionally under-represented in their labour force. However, a number of studies have reported that when flexible working initiatives were introduced, employee turnover and absenteeism decreased while job satisfaction improved. For example, when extended maternity leave is offered women do actually return to work sooner, stay with their employer longer and are absent less often. The recognition of conflicts between employees' work and their personal lives and then helping them to manage these conflicts could increase psychological availability for and engagement with work. Employees among people with special needs, for example, tend to have more motivation, better attendance, and are more punctual and productive because of their appreciation of the opportunity to work given to them by working flexibly. According to Hodge (1999: 33) 'the commitment and the loyalty that disabled people bring to the workplace is an added bonus. When employees feel that their employers treat them fairly and with understanding they 
are far more likely to remain loyal to a company and therefore their employment relationships and performance will be strengthened. Employees who feel that they are treated well and fairly and are valued tend to stay longer with their employer and put more effort into their work.

Many jobs are becoming increasingly physically and mentally demanding in terms of workload and time, and very stressful. A survey of managers' changing experiences in the UK found that as a result of working long hours 71 percent had health problems, 79 percent had their spouse/partner relationships affected, 86 percent had poor relationships with their children, and 68 percent had their work performance worsened (Quality of Working Life Survey for the DofEE, 1999). Family friendly policies may be used to reduce the amount of stress and pressure that employees suffer from in trying to balance between full-time workload and family commitments. Employers who implement family friendly policies attempt to overcome such pressures on their employees and in turn they benefit from them becoming more committed, less stressed and able to concentrate better on their work.

\section{Discussion}

There is a difference between having a policy and implementing it. Claiming to be a family friendly employer is in many cases a public relations and a smoke screen approach. Flexible working may be seen to promote equality of employment but in reality it could be used as a means of exploiting vulnerable employees from women, the disabled, the old and the ethnic minorities. Most employees who work flexibly are at the lower end of the wages scale and they are most likely to feel the worst effects of family friendly policies. It seems that the debate surrounding the feasibility of flexible working and family friendly policies leads to the following issues that should be taken into consideration in employee relations and job creation in current labour market trends.

\subsection{Flexibility and adaptability to change}

Flexibility is one of the key words that is associated with family friendly policies and is most commonly connected with working patterns. Practically, flexibility in organizations is a process of reacting and adapting to internal and external changes. In fact organizations can have different forms of flexibility, as Grant (1996) argued, depending on the situation of change they are in and pressures from the environment in which they operate. Much of the rhetoric on flexibility has been enclave in the industrial relations academic circles with some political attraction because of its effect on discrimination issues. However, flexible working and family friendly policies are introduced in order to adapt to changes in the labour market, in the economy and in the social structure. For all the reasons made it can be argued that, as Pettinger (1998: 2) put it, 'flexibility is a corporate attitude and the flexible 
workforce is the product'. It is not a matter of flexibility or being family friendly it is just a process of managing change and time effectively so employees complete their workloads in fewer hours than before. This explains the fact that there are many different ways of implementing family friendly policies. The workplace is undergoing rapid change that puts pressure on managers to manage their resources in a way that cuts costs and improves productivity.

The most important change in societies is a redefinition of the working family and the decline in the traditional family model of male breadwinner and female housewife as many women enter the labour market but parenting has stayed more or less the same. A study by Brannen and Moss (1988) looked into the socially constructed 'good' father and 'good' mother roles and found that the 'good' mother was expected to give up paid employment in order to look after the children on a full-time basis at least until the children start school. The 'good' father social construction dictated that his main responsibility should be to provide financially for his wife and children. In a third social construction Brannen and Moss (1988) define a 'good' worker as a person who works full-time, has a continuous record of employment until retirement and does not allow domestic responsibilities to conflict with those at work. Although the increased participation by women in the work place cannot be doubted, childcare or parenting, to be more specific, remains still predominantly the responsibility of the mother despite the changes in technology and some family values. It is true that more men are taking responsibility for childcare than they were in the past but women still take the biggest responsibility of parenting and caring. This is why the concept of 'family friendly' is inextricably linked to women in the workplace. Employers have been faced with the reality of having to employ a workforce with different needs and adapt to socio-economic changes by attracting and retaining talented and skilful employees regardless of their family commitments.

\subsection{The most vulnerable is the most available workforce}

It is very often argued that the vulnerable workforce among women, the disabled, the old and ethnic minorities are most likely to benefit from the introduction of flexible working and family friendly policies but the analysis the labour market composition of many societies shows that the available workforce in the labour market is actually the so-called vulnerable workforce. That means that employers have no choice just to employ who they can attract to their job vacancies. Traditionally men were the main bead winners in the family while women were responsible for domestic duties and child rearing. Most men worked full-time and there was no significant need for flexibility or family considerations in the workplace. Age was never a barrier for men seeking employment as long as they were able to work. Even people with disabilities were provided for to the extent that they did not need to work or they had jobs that were just suitable for them. Today we have a different 
labour market where women make up a significant proportion of the workforce, where more people with disabilities seek employment and an increasing number of older and healthier people can still work after retirement age. For example, more than 40 percent of those employed in the UK are women and many of them may prefer to work flexibly. This is why in most of the studies that have been carried out on the subject of flexible working and family friendly policies the emphasis has been made on women wishing to combine work with domestic and childcare commitments. However, it is important to analyse the type of jobs women do and the sectors in which they work in order to understand the extent to which family friendly policies have benefited them. It is very often reported that the most of the jobs available to women remain in the traditionally female orientated sector of the services and a high proportion of them work is unskilled and low paid jobs.

Moreover, it is also argued that the introduction of flexible working and family friendly policies contributes to 'the marginalization of women at work, as quite often these jobs are in the lower paid categories' (Fynes et al., 1996: 7). Part-time work, for example, is a trap leading to women's marginalization in the labour market (Beechey and Perkins (1987) and provides 'the organization with a cheap source of expandable labour' (Newell, 1995: 155). Many women prefer to work flexibly after maternity leave but they found themselves with limited choices between having to work flexibly in jobs that may be lower in status than their previous ones. Cooper and Lewis (1995) pointed out that the combined effects of career development based on full-time work and the lack of childcare facilities predominately disadvantage women with dependents because of attitudinal stereotypes and physical barriers to full-time employment.

\subsection{Managing diversity versus equal opportunity}

In many organisations, the implementation of family friendly policies is part of an overall strategy of managing diversity rather than just an equal opportunities initiative. They aim to maximise the utilization of current and potential workforce by ensuring that all employees are valued and given the opportunity to contribute effectively to the organization and to develop their career potentials. They value different employee perspectives and type of contribution. This strategy of managing diversity makes more sense in economic terms than the moral or ethical dilemma of equal opportunities. For many employers, legislative pressures for equal opportunities may not be as strong as the economic objectives of introducing flexible working and family friendly policies. The process of managing diversity is to improve the opportunities that are available to employees regardless of whether they are men, women, old or young, able or disabled. Therefore the lack of understanding of the difference between managing diversity and being an equal opportunities employer might have led some employers to adopt family friendly policies in name and have had no initiatives to change the status quo of being reactive rather than active in implementing such policies. Even when attempts are made to implement such 
policies, diversity is ignored as most employers concentrate on women with young children and occasionally those with eldercare responsibilities and not recognising the fact that the workforce is becoming increasingly diverse.

Focusing on the issue of 'family' and not on 'diversity' creates conflicts of interests in the workplace because employees without family commitments could be discriminated against if they were not given the benefits that are more suitable to their employment and personal needs. In this respect, Lewis (1996) argued that family friendly benefits should not be perceived as perks to those with family commitments but must be seen as a basic employee right akin to health and safety at work. Family friendly policies may benefit workers with health problems, working nearer to retirement or the already retired people, those who may have to care for an elderly relative or friend, and those who may wish to study to enhance their career prospects. Therefore the introduction of flexible working practices and family friendly policies should be seen as part of a corporate strategy for managing diversity rather than just a mere equal opportunities requirement.

\subsection{Managing time at work and time off work}

The whole concept of flexibility and family friendliness revolves around the issue of time at work and time off work. Time seems to be never enough especially for those who have conflicting commitments. In order to achieve high productivity and efficiency levels employers must make the best use of their employees' time. In other words they have to manage the work and non-work time of their employees. Flexible working practices are flexible working times such as part-time work, flexi-time and so on. Maternity and paternity leave are time off work. With advances in the use of information technologies more and more employees work at and away from the workplace. Working time can now be easily extended to non-working time especially for professional employees who tend to work longer hours in and away from their workplaces. Responding to the demands on employees' time is what employers do when planning, designing and implementing work operations to enable all employees to balance between their work and non-work commitments. Therefore managing time is key to organizational success especially when there an increasing demand for working away from the normal workplace.

\section{Conclusions}

Flexible working practices and family friendly policies are used for a wide range of reasons and in a variety of different ways. They are supposed to be used to benefit both the employee and the employer as they are normally a means to attract and retain employees in order to maintain operational levels that meet the demands of clients/customers. There is some truth in the belief that flexible working practices are mainly created to benefit the employer but many employees request them because 
they basically have to or need to work flexibly. Yes, there are intrinsic elements of exploitation in implementing such practices and policies because of the vulnerability and the insecurity of the majority of people opting to work flexibly. For many employers the cost of implementing family friendly policies may be high but the cost of not implementing them may be even higher because it is more expensive to find and recruit new employees and train them than to have in place policies that support existing employees to work flexibly under any circumstances. Many organisations have family friendly policies to attract and retain their good employees through whom it will be possible to gain competitive advantage in a competitive business environment. However, the fallacy of family friendly policies is the assumption that only women are affected by them or who need them, ignoring the fact that men as well as women have other commitments rather than just work and it is not just women with childcare responsibilities who wish to spend time at home because even those who do not have children - whether be male or female, young or old, able or disabled - may need to work flexibly for personal, family, health, economic, political or social reasons. They benefit both the employer and the employee when implemented as a strategy for managing diversity in an organisation. With the ever-changing economy, work habits and social structure it is important for many organizations to accommodate the needs of all kind of employees. By doing so, employers can have better recruitment, improved retention, better employee morale, committed employees, and improved organisational performance.

\section{EKSPLORACJA EFEKTÓW ELASTYCZNYCH FORM PRACY I POLITYKI PRZYJAZNEJ RODZINIE NA ZATRUDNIENIE I ZAMOŻNOŚĆ PRACOWNIKÓW NIEUPRZYWILEJOWANYCH}

Streszczenie: W artykule poruszono wiele kontrowersyjnych kwestii, podejmując próbę oceny skutków elastycznych metod pracy i polityki przyjaznej rodzinie w zakresie zatrudnienia i dobrobytu ludzi, głównie osób niepełnosprawnych, starszych oraz kobiet i mężczyzn z obowiązkami rodzicielskimi. W ciągu ostatnich lat wiele rządów broniło idei elastycznej pracy z oczywistych powodów politycznych i gospodarczych, podczas gdy większość pracodawców, którzy zaakceptowali lub nawet wdrożyli takie praktyki i polityki, kierowała się powodami czysto ekonomicznymi i biznesowymi. Niniejsze opracowanie jest próbą wyjaśnienia pojęcia elastycznej pracy, polityki przyjaznej rodzinie, aby następnie zbadać przyczyny i procedury realizacji takiej polityki. Stwierdzono, że polityka przyjazna rodzinie może być użytecznym środkiem zaspokajania potrzeb zarówno pracodawców, jak i pracowników, w zależności od sposobu, w jaki są one realizowane i osób, które czerpią z nich korzyści.

Słowa kluczowe: elastyczne metody pracy, polityka przyjazna rodzinie, elastyczność w miejscu pracy

\section{REFERENCES}

[1] Atкinson J., 1984, Manpower Strategies for Flexible Organizations, Personnel Management, August 1984, pp. 28-31.

[2] Atkinson J., 1987, Flexibility or Fragmentation?, The United Kingdom Labor Market in the Eighties, Labour and Society, 12, 1, pp. 87-105. 
[3] Allan A. and Daniels L., 1999, Part-time Workers, Short Run Press: Exeter.

[4] Beechey V. and Perkins T., 1987, A Matter of Hours: Women, Part-time and the Labour Market, Cambridge: Polity Press.

[5] Blossfeld H.P. and Hakim C. (eds.), 1997, Between Equalisation and Marginalisation, Oxford University Press, Oxford.

[6] Branine M., 1998, The Logic of Job Sharing in the Provision and Delivery of Health Care, Journal of Management in Medicine, 12:1 pp. 63-72.

[7] Branine M., 1999, Part-time work in the public health service of Denmark, France and the UK, The International Journal of Human Resource Management, 10(3) pp. 411-428.

[8] BRAnine M., 2003, Part-time work and job sharing in health care: Is the NHS a family friendly employer, Health Organization and Management, Vol. 17, No. 1, 2003, pp. 53-68.

[9] BRANine M., 2004, Job sharing and equal opportunities under the new public management in local authorities, International Journal of Public Sector Management, Vol. 17, No. 2, 2004, pp. 136-152.

[10] Curson C., 1986, Flexible Patterns of Work, London: Institute of Personnel Management.

[11] Dastmalchian A. and Blyton P., 1998, Organizational flexibility in cross-national perspective, The International Journal of Human Resource Management, 9(3), pp. 437-444.

[12] DTI (Department of Trade and Industry), 2003, Balancing Work and Family Life: Enhancing Choice and Support for Parents, HM Treasury, London.

[13] EOR (Equal Opportunities Review), 1994, Part-time workers lose out on training in the NHS, Equal Opportunities Review, No. 54, March/April, 1994: 5.

[14] EOC (Equal Opportunities Commission), 2001, Good Practice Guide, How to Manage Flexibility in the Workplace?, EOC, London.

[15] Felstead A. and Jewson N., 1999, Global Trends in Flexible Labour, MacMillan Business, London.

[16] Felstead A., Jewson N., Phizacklea A. and Wlaters S., 2002, Opportunities to Work at Home in the Context of Work-Life Balanc, Human Resource Management Journal, 12(1), pp. 54-77.

[17] Gherardi S. and Murgia A., 2012, By Hook or By Crook: Flexible Workers between Exploration and Exploitation, in Mikael Holmqvist, André Spicer (ed.), Managing Human Resources by Exploiting and Exploring People's Potentials (Research in the Sociology of Organizations, Vol. 37), Emerald Group Publishing Limited, pp. 75-103.

[18] Grover S. and CrooKer K., 1995, Who appreciates family-responsive human resource policies: the impact of family-friendly policies on the organizational attachment of parents and non-parents, Personnel Psychology, Vol. 48, No. 2, pp. 271-289.

[19] Накім C., 1997, A sociological perspective on part-time work, in Blossfield H.P. and Hakim C. (eds.), Between Equalization and Marginalization: Women Part-time Workers in Europe and the USA, Oxford University Press, Oxford.

[20] Накім C., 2000, Work-Lifestyle Choices in the $21^{\text {st }}$ Century-Preference Theory, Oxford University Press, Oxford.

[21] Hammond D., 2001, Small companies urged to reap the benefits of $H R$, People Management, CIPD, London. 
[22] Higginbotтom K., 2000, Flexible working policy rings in rewards for BT, People Management, CIPD, London.

[23] IRS Employment Trends, 1996, Still a flexible friend - a survey of flexitime arrangements, IRS Employment Trends, 603, march 1996, pp. 5-16.

[24] Labour Force Survey, 1996, Women in the labour market: results from the spring 1996 Labour Force Survey, Labour Market Trends, March 1997, The Government Statistical Service, London.

[25] Leighton P. and Syrett M., 1989, New Work Patterns: Putting Policy into Practice, London, Pitman Publishing.

[26] Lewis S. and LewIS J. (eds.), 1996, The Work-Family Challenge: rethinking employment, Sage, London.

[27] LEwIS S., 1996, Rethinking employment: An organizational culture change framework, in Lewis S. and Lewis J. (eds.), The Work-Family Challenge, Sage, London.

[28] LEwIS S., 2001, Restructuring workplace cultures: the ultimate work-family challenge?, Women in Management Review, 16:1, pp. 21-29.

[29] Mondy R.W., Noe R.M. and Premeaux S.R., 2000, Human Resource Management, Prentice Hall, New Jersey.

[30] Newell S., 1995, The Healthy Organization - Fairness, Ethics and Effective Management, Routledge, London.

[31] Pettinger R., 1998, Managing the Flexible Workforce, Cassell, London.

[32] Pollert A., 1988a, The "flexible firm": Fixation or fact?, Work, Employment and Society, 2(3), pp. 281-316.

[33] Pollert A., 1988b, Dismantling flexibility, Capital and Class, 34(1), pp. 42-75.

[34] Steele M., 1993, HRM: An opportunity for women, in Towers B. (ed.), The Handbook of Human Resource Management, Blackwell, Oxford.

[35] Stredwick J. and Ellis S., 1998, Flexible Working Practices - Techniques and Innovations, IPD, London.

[36] Stuart M., Grugulis I., Tomlinson J., Forde C. and MacKenzie R., 2013, Reflections on work and employment into the 21st century: between equal rights, force decides Work, employment and society, 27(3), pp. 379-395.

[37] Syrett M., 1983, Employing Job Sharers, Part-time and Temporary Staff, IPM, London.

[38] Thatcher M., 1996, Family favourites (Winners of Parents at Work Awards recognizing family-friendly policies among UK companies), People Management, Vol. 3 (20), October.

[39] Wooding N., 1995, Understanding Flexibility - A guide to flexible opportunities inside the workplace, Welsh Common Services Agency. 